OPEN ACCESS

Edited by:

Xuesheng Liu,

First Affiliated Hospital of Anhui

Medical University, China

Reviewed by:

Yang Yu,

Tianjin Medical University, China Kenji Hashimoto,

Chiba University, Japan

Tao Tao,

Southern Medical University, China Joseph Cichon,

University of Pennsylvania,

United States

*Correspondence:

Hui Qiao

qiaohui240@163.com

Tianzuo L

litz@bjsjth.cn

†These authors have contributed equally to this work

Specialty section:

This article was submitted to Pain Mechanisms and Modulators, a section of the journal

Frontiers in Molecular Neuroscience

Received: 19 December 2021

Accepted: 24 January 2022

Published: 24 February 2022

Citation:

Miao H, Yu K, Gao D, Lin X Cao Y, Liu X, Qiao H and Li T (2022) A Bibliometric Analysis of Research on

Ketamine From 2001 to 2020.

Front. Mol. Neurosci. 15:839198. doi: 10.3389/fnmol.2022.839198

\section{A Bibliometric Analysis of Research on Ketamine From 2001 to 2020}

\author{
Huihui Miao+, Kang Yu+, Danyang Gao, Xiaowan Lin, Ying Cao, Xiao Liu, Hui Qiao* and \\ Tianzuo Li*
}

Department of Anesthesiology, Beijing Shijitan Hospital, Capital Medical University, Beijing, China

Background: Ketamine is an intravenous anesthetic with analgesic effects that has a rapid onset and short duration of action. Many studies have been conducted on the use of ketamine; however, the quantity and quality of such studies have not been reported. Therefore, we aimed to conduct a bibliometric analysis of research on ketamine from 2001 to 2020.

Methods: We used the Web of Science database to get publications on ketamine from January 2001 to December 2020. Various bibliographic information was collected, including the number of publications, year of publication, country of origin, journal name, research hotspots, citation count, and author information.

Results: A total of 5,192 articles were included in the analysis. The United States published the highest number of papers on ketamine and the United States participated in publishing the most papers and disclosure funds. The types of articles in clinical trials were cited more frequently. Most articles on ketamine were published in the journal Anesthesia and Analgesia. Furthermore, the antidepressant effect of ketamine has been a research hotspot for the last 20 years.

Conclusion: This study provided a comprehensive analysis of research on ketamine and highlighted the growing interest in ketamine and its antidepressant effects.

Keywords: ketamine, bibliometric analysis, clinical anesthesia, analgesic, depression

\section{INTRODUCTION}

Ketamine is a non-competitive ionized N-methyl-D-aspartate (NMDA) receptor antagonist. NMDA receptors are widely present in the central and peripheral nervous systems. Blocking NMDA channels is the main mechanisms of ketamine' pharmacology effect (Johnson et al., 2015). It is generally believed that ketamine selectively blocks cortical communication system and the thalamo-cortical system, a dissociative anesthesia state in which pain sensation disappears and consciousness may partially exist (Schmid et al., 1999). In addition, ketamine could also promote the endogenous opioid peptides release; affect the metabolism of monoamine neurotransmitters; stimulate $\mu, \delta$, and $\kappa$ opioid receptors; and block $\mathrm{Na}^{+}$and $\mathrm{Ca}^{2+}$ plasma channels to exert analgesic effects (Hirota and Lambert, 1996). The effects of ketamine are dose-dependent; in adults, the recovery period after the traditional clinical dose of ketamine for anesthesia is sometimes accompanied by a variety of adverse reactions, such as dreams and hallucinations. Nevertheless, it has become one of the most commonly used basic drugs in pediatric clinical anesthesia because of 
its convenient route of administration and less respiratory depression; it is often used for pediatric anesthesia and perioperative analgesia. In addition, the intraspinal injection of ketamine as an auxiliary drug has analgesic and preemptive analgesic effects. Besides, the effect and mechanism study of ketamine on antidepressant is increased gradually, therefore, the overview and publication state on ketamine was analyzed in this study.

Bibliometric analyses can evaluate influential papers in a certain field and objectively analyze their study impact. At present, there is no scientific report on the bibliometric analysis of high-quality and highly cited papers on ketamine. The purpose of our research was to investigate the research hotspots and publication trends regarding ketamine, which helps understand its current research status and provides clinicians with accurate medication standards and new ideas for medication. Using bibliometric methods, 5,192 papers on ketamine from 2001 to 2020 were evaluated and their nature, content, and changes over time were analyzed.

\section{MATERIALS AND METHODS}

\section{Search Strategy}

We used the Web of Science database to investigate publications on ketamine between 2001 and 2020. We used "ketamine" as the search title, limited the article type to "article or review," and only searched for English publications. We collected the following bibliometric information: year of publication, country, journal, number of citations, authors, funding, disciplines, institutions, and topics. We did not use any exclusion criteria.

\section{Statistical Analysis}

The CiteSpace software was used for bibliometric analysis. Statistical analysis was performed using the SPSS software (version 21.0; IBM Corp., Armonk, NY, United States). The data were expressed as mean (range) or percentage. Categorical and continuous variables were analyzed using the $\chi^{2}$-test and independent-sample $t$-test, respectively. Correlation coefficients $(\mathrm{r})$ and $P$-values were calculated using the Spearman's test. Statistical significance was set at $P<0.05$.

\section{RESULTS}

\section{Year and Country of Publication}

In the first 7 years (2001-2007), the number of articles published on ketamine was around 120 per year. From 2008 to 2010, there were no major fluctuations in the number of publications per year. Since 2011, the number of papers published on ketamine has shown an increasing trend (Figure 1A). The year with the largest number of papers published was $2020(n=515)$. American authors published the highest number of articles on ketamine $(n=1,685)$, followed by China $(n=675)$ and Germany $(n=313)$. The average number of citations per article published by British authors was 36.55, followed by the United States (34.81) and France (32.54) (Table 1). We also analyzed the cooperation between countries for each published article (Figure 1B) and found that research cooperation was highest with the United States. In addition, there were more papers co-authored by Chinese authors than those of other nationalities.

\section{Authors and Institutions}

We investigated the top 20 corresponding authors and their institutions according to the number of articles published. The corresponding author with the highest number of publications was Hashimoto Kenji at Chiba University with 46 published papers on ketamine, followed by McIntyre Roger $S$ at the University Health Network in Toronto with 28 publications. We used the $\mathrm{H}$-index to assess the number and level of academic output of the researchers. The highest $\mathrm{H}$-index was that of Hashimoto Kenji $(\mathrm{H}$-index $=24)$, followed by Zarate Carlos A from the National Institute of Mental Health (H-index $=16)$. More detailed values are presented in Table 2 . Next, we analyzed the top 20 institutions; the institution with the highest number of publications was University of California System $(n=135)$, followed by the National Institutes of Health $(n=124)$ and Yale University $(n=121)$. We also analyzed the H-index for each institution; the University of London had the highest $\mathrm{H}$-index (H-index $=131)$, followed by the National Institutes of Health $(\mathrm{H}$-index $=47)$ and Yale University $(\mathrm{H}$-index $=43)$. More detailed data are presented in Table 3 and Figure 2.

\section{Subjects and Funds}

We analyzed all the journal disciplines that included articles on ketamine in the past 20 years and compiled statistics on these disciplines. We found that most research on ketamine was published in the discipline of neuroscience ( $n=1,363 ; 18 \%)$ followed by pharmacology and pharmacy $(n=1,054 ; 14 \%)$ and psychology ( $n=1,023 ; 13 \%)$, as shown in Figure 3 . We also analyzed the funding agencies mentioned in these articles, and the top 10 funding agencies supporting research on ketamine are shown in Table 4. They included three American institutions, two European, Brazilian, and Japanese institutions, and one Chinese institution. Among them, the United States Department of Health and Human Services $(n=637)$ and National Institute of Health $(n=634)$ funded the maximum number of studies were from the United States, followed by the National Natural Science Foundation of China $(n=289)$.

\section{Journal Analysis}

Next, we investigated the top 20 journals with articles published on ketamine, as shown in Table 5. The top 20 journals were established by the number of articles on ketamine they published during this period. Among them, the journal with the highest number of articles was Anesthesia and Analgesia $(n=129$; each article was cited 46.39 times on average), followed by the journals Veterinary Anesthesia and Analgesia ( $n=108$; each article was cited 13.94 times on average) and Psychopharmacology ( $n=105$; each article was cited 4.93 times on average). We quantified the number of publications in various journals per year and found that the number of publications in the journals Veterinary Anesthesia and Analgesia and Behavioral 


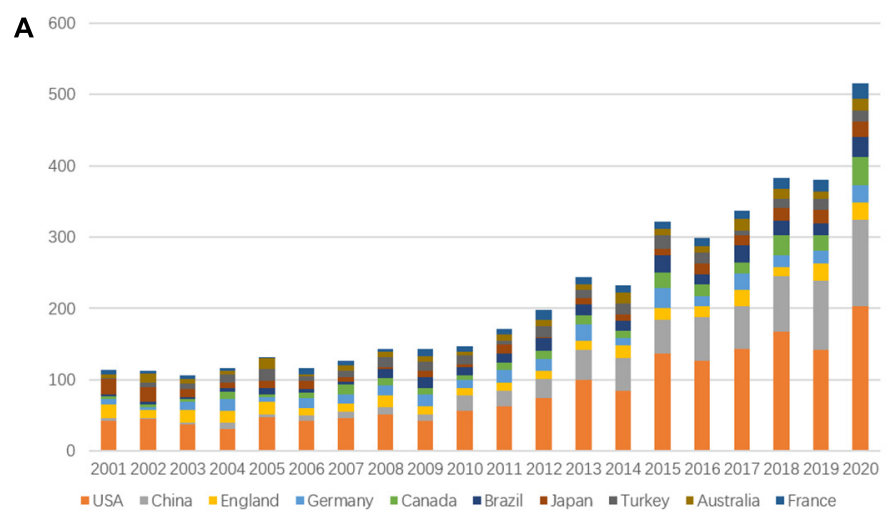

B

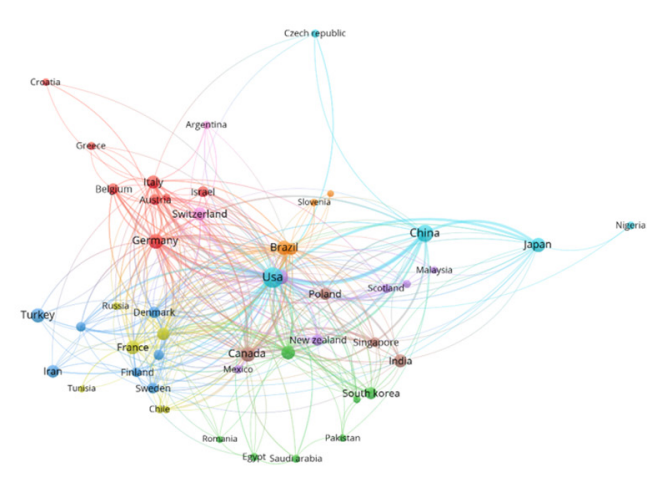

FIGURE 1 | The year and country in which the articles on ketamine were published. (A) The number of articles published in different countries each year. (B) The country contact map for co-published articles.

Brain Research increased every year in the past 10 years. More detailed data are presented in Figure 4.

\section{Citations}

In general, the number of citations varied, and we identified the 20 most cited articles. These 20 articles included 9 basic research, 1 review, and 10 clinical research articles. Based on the effects of ketamine, we classified the research content of these articles as follows: 10 articles, antidepressant effects; three articles, antischizophrenic effects; four articles, effects on perioperative pain; and three articles, effects on neurotoxicity (Figures 5A,B). The top three cited articles were "Cellular mechanisms underlying the antidepressant effects of

TABLE 1 | Number of publications and citations by country.

\begin{tabular}{|c|c|c|c|}
\hline Countries & Articles & Citations & Average citations per article \\
\hline United States & 1,685 & 58,655 & 34.81 \\
\hline China & 675 & 11,101 & 16.45 \\
\hline Germany & 313 & 8,230 & 26.29 \\
\hline England & 307 & 11,222 & 36.55 \\
\hline Canada & 262 & 7,175 & 27.39 \\
\hline Brazil & 256 & 4,717 & 18.43 \\
\hline Japan & 234 & 7,013 & 29.97 \\
\hline Turkey & 227 & 3,413 & 15.04 \\
\hline France & 195 & 6,345 & 32.54 \\
\hline Australia & 184 & 4,921 & 26.74 \\
\hline India & 166 & 2,063 & 12.43 \\
\hline Italy & 144 & 3,174 & 22.04 \\
\hline Switzerland & 137 & 3,787 & 27.64 \\
\hline Iran & 117 & 1,388 & 11.86 \\
\hline Netherlands & 107 & 4,726 & 44.17 \\
\hline South Korea & 98 & 1,694 & 17.29 \\
\hline Poland & 85 & 1,595 & 18.76 \\
\hline Spain & 79 & 1,253 & 15.86 \\
\hline Denmark & 65 & 1,774 & 27.29 \\
\hline New Zealand & 64 & 1,408 & 22 \\
\hline
\end{tabular}

ketamine: Role of alpha-amino-3-hydroxy-5-methylisoxazole4-propionic acid receptors," (766 citations) (Maeng et al., 2008); "NMDAR inhibition-independent antidepressant actions of ketamine metabolites," (724 citations) (Zanos et al., 2016); and "Antidepressant efficacy of ketamine in treatment-resistant major depression: A two-site randomized controlled trial," (621 citations) (Murrough et al., 2013). We found that the top four cited papers were all related to the antidepressant effects of ketamine, and ten out of these twenty articles were on the antidepressant mechanism and clinical applications of ketamine (Table 6).

In addition, we analyzed the correlation between the average number of citations, year of publication, and impact factors of the 20 most cited journals; the average number of citations, year of publication $(R=0.5, P<0.001$, and impact factor $(R=0.4419$, $P=0.0014)$ were all significantly correlated with one another (Figures 5C,D).

\section{Research Hotspots and Publication Trends}

Research hotspots were identified by the frequency of two keywords that appeared together in the same publication. Additionally, the size of the circles and the thickness of the line represented the frequency of co-occurrence of the keywords. We hypothesized that the hotspots in research on ketamine changed with time; therefore, we classified and summarized all the literature research hotspots every 10 years. From 2001 to 2010, the research interest on ketamine was more about the mechanism of action in neuropathy or brain function, as shown in the red cluster. "Depression" was associated with anesthesia or analgesia, as shown in the green cluster (Figure 6A). We found that the research hotspots of articles on ketamine was higher from 2010 to 2020 than in the previous 10 years. "Depression" was the most frequently encountered keyword that appeared with the mechanism cluster (in red), indicating a greater focus on identifying the molecular targets. Our search statistics on the topic of articles in the past 10 years also confirmed that the antidepressant effect of ketamine was the focus of these articles (Figure 6B). 
TABLE 2 | The 20 authors with the highest number of publications.

\begin{tabular}{|c|c|c|c|}
\hline Author name & Institution & Number of articles & H-index \\
\hline Hashimoto, Kenji & Chiba University & 46 & 24 \\
\hline Mclntyre, Roger S & University Health Network Toronto & 28 & 8 \\
\hline Dahan, Albert & Leiden University Medical Center & 22 & 9 \\
\hline Ning, YuPing & Guangzhou Medical University, Guangzhou Huiai Hospital & 22 & 8 \\
\hline Su, TungPing & National Yang Ming Chiao Tung University & 18 & 9 \\
\hline Yang, JianJun & Nanjing University, Jinling Hospital & 18 & 9 \\
\hline Zarate, Carlos A., Jr. & $\mathrm{NIH}$ National Institute of Mental Health & 18 & 16 \\
\hline Thormann, Wolfgang & University of Bern & 15 & 8 \\
\hline Wang, Cheng & US Food \& Drug Administration & 15 & 12 \\
\hline Gao, Li & Northeast Agricultural University & 14 & 6 \\
\hline Kanungo, Jyotshna & US Food \& Drug Administration & 14 & 9 \\
\hline Morgan, Celia J. A & University of London & 14 & 14 \\
\hline Reus, Gislaine Z & Universidade do Extremo Sul Catarinense & 14 & 9 \\
\hline Zugno, Alexandra I & Universidade do Extremo Sul Catarinense & 14 & 10 \\
\hline Abdallah, Chadi G & Yale University & 13 & 9 \\
\hline Kuo, HannChorng & Buddhist Tzu Chi General Hospital & 13 & 7 \\
\hline Murrough, James W & Icahn School of Medicine at Mount Sinai & 13 & 13 \\
\hline Kabbaj, Mohamed & Florida State University & 12 & 14 \\
\hline Rodrigues, Ana Lucia S & Universidade Federal de Santa Catarina & 12 & 6 \\
\hline Wainer, Irving W & Cooper Medical School of Rowan University & 12 & 10 \\
\hline
\end{tabular}

TABLE 3 | Top 20 author institutions in terms of number of articles published.

\begin{tabular}{|c|c|c|c|c|c|}
\hline Institution & Articles & Citations & Average citations per article & H-index & Degree centrality \\
\hline University of California System & 135 & 3,524 & 26.1 & 31 & 234 \\
\hline National Institutes of Health NIH USA & 124 & 8,350 & 67.34 & 47 & 66 \\
\hline Yale University & 121 & 6,592 & 54.48 & 43 & 346 \\
\hline University of London & 109 & 13,1619 & 25.35 & 131 & 90 \\
\hline Harvard University & 99 & 4,279 & 43.22 & 35 & 97 \\
\hline University of Texas System & 89 & 3,633 & 40.82 & 29 & 213 \\
\hline US Department of Veterans Affairs & 84 & 3,781 & 45.01 & 35 & 28 \\
\hline Institut National de la Sante et de la Recherche Medicale Inserm & 80 & 2,896 & 36.2 & 28 & 35 \\
\hline Baylor College of Medicine & 61 & 3,505 & 57.46 & 27 & 139 \\
\hline Assistance Publique Hopitaux Paris Aphp & 55 & 2,553 & 46.42 & 26 & 6 \\
\hline Columbia University & 54 & 2,194 & 40.63 & 26 & 112 \\
\hline Chiba University & 53 & 2,229 & 42.06 & 27 & 62 \\
\hline University of Toronto & 52 & 1,955 & 37.6 & 23 & 258 \\
\hline University of Bern & 51 & 1,146 & 22.47 & 22 & 25 \\
\hline Chinese University of Hong Kong & 50 & 1,003 & 20.06 & 20 & 70 \\
\hline State University System of Florida & 50 & 1,119 & 22.38 & 19 & 31 \\
\hline Icahn School of Medicine At Mount Sinai & 47 & 5,109 & 108.7 & 29 & 173 \\
\hline Mayo Clinic & 46 & 1,494 & 32.48 & 20 & 49 \\
\hline Universidade de São Paulo & 45 & 685 & 15.22 & 13 & 36 \\
\hline University of Pittsburgh & 44 & 1,731 & 39.34 & 23 & 73 \\
\hline
\end{tabular}

\section{DISCUSSION}

In this study, we searched for articles on ketamine published in the Web of Science database from 2001 to 2020 and analyzed their basic information. We also conducted a correlation analysis of the articles citation frequencies. To avoid the differences caused by the year of publication of the article, we chose the average annual citation frequency as a reference indicator and performed a correlation analysis between the year of publication and the impact factor of the articles. The correlation analysis revealed that the articles published later had a higher citation frequency and impact factor. This indicates that ketamine has received increasing attention in recent years with higher numbers of open-access publications on it. Finally, the hotspot trend analysis indicated that an increasing amount of research on 

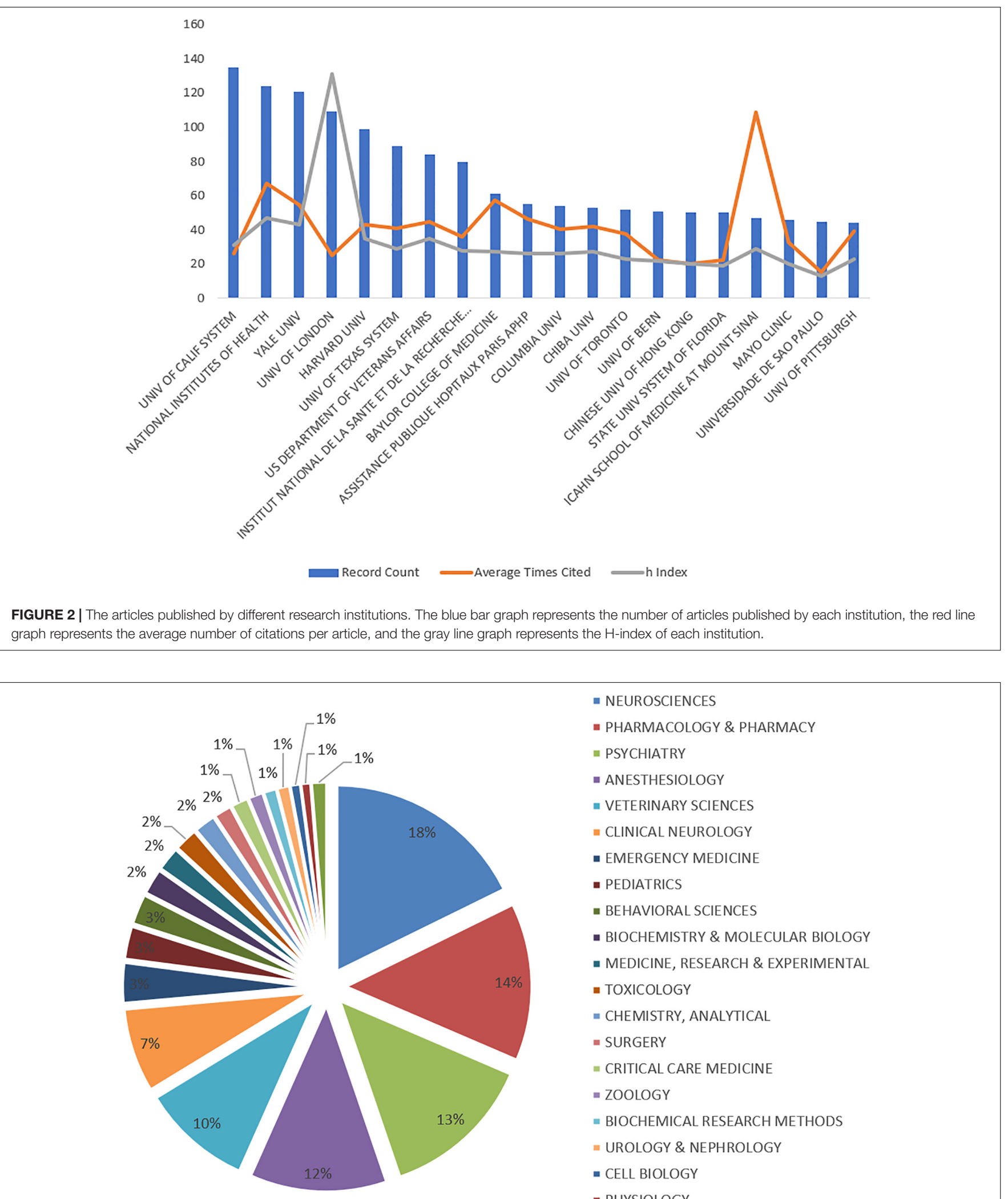

- NEUROSCIENCES

- PHARMACOLOGY \& PHARMACY

- PSYCHIATRY

- ANESTHESIOLOGY

- VETERINARY SCIENCES

- CLINICAL NEUROLOGY

- EMERGENCY MEDICINE

- PEDIATRICS

- BEHAVIORAL SCIENCES

- BIOCHEMISTRY \& MOLECULAR BIOLOGY

- MEDICINE, RESEARCH \& EXPERIMENTAL

- TOXICOLOGY

= CHEMISTRY, ANALYTICAL

= SURGERY

= CRITICAL CARE MEDICINE

- ZOOLOGY

= BIOCHEMICAL RESEARCH METHODS

- UROLOGY \& NEPHROLOGY

- CELL BIOLOGY

- PHYSIOLOGY

- OTHERS

FIGURE 3 | The proportion of articles published in different disciplines. 
TABLE 4 | Top 10 funding agencies with publication volume.

\begin{tabular}{llc}
\hline $\begin{array}{l}\text { Rank } \\
\text { number }\end{array}$ & Funding agency & $\begin{array}{c}\text { Number of } \\
\text { publications }\end{array}$ \\
\hline 1 & $\begin{array}{l}\text { United States Department of Health Human } \\
\text { Services }\end{array}$ & 637 \\
2 & National Institutes of Health United States & 634 \\
3 & National Natural Science Foundation of China & 289 \\
4 & European Commission & 253 \\
5 & Conselho Nacional de Desenvolvimento & 103 \\
6 & Cientifico e Tecnologico CNPq & 86 \\
7 & NARSAD & 70 \\
8 & UK Research Innovation & 65 \\
9 & Coordenacao de Aperfeicoamento de Pessoal & 57 \\
10 & de Nivel Superior CAPES & \\
& Ministry of Education Culture Sports Science & 45 \\
\hline
\end{tabular}

ketamine in the past 10 years has focused on its mechanism as an antidepressant.

The journals wherein articles on ketamine were published gradually changed from Anesthesia and Analgesia and Anesthesiology to Behavioral Brain Research and Veterinary Anesthesia and Analgesia. This could be attributed to the fact that ketamine has become a hot topic of research in recent years owing to its antidepressant effects and multiple animal experiments involving it. In terms of co-authorship (Supplementary Figure 1), we found that Rosenblat, Joshua D, Nasri, Flora, and Iee, Yena et al. co-authored more articles on ketamine, which may be since they are from the same institution or from the same country. Among the cooperative institutional relationships (Supplementary Figure 2), University of California System and university of texas system take great part and co-operative with other institutions frequently. Some other institutions include Guangzhou Medical University, Chiba University, Chinese University of Hong Kong, and Nanjing University were also co-operative closely. The amount of cooperation between these institutions is much higher than that of other institutions, and the number of publications of these institutions is also higher than that of other institutions, which is consistent with our analysis results. By analyzing the correspondence between authors and institutions, we found that Hashimoto, the author with the largest number of papers, and Chiba University, the institution where Kenji works, also published more papers ( $n=53$ ), ranking 12th, and the author Morgan, who was the 12th author with the same total number of papers. The University of London, where Celia J. A belongs, ranks fourth and Yale University, where the authors of the 15th publishing volume, Abdallah and Chadi $G$, ranks third in terms of total publication volume. This shows that the institutions of authors with high publication volumes tend to have higher publication volumes, and these authors and institutions are more willing to collaborate with other institutions on co-authoring articles.

In recent years, ketamine has received considerable attention in the treatment of clinical depression, which has aroused a conventional drug in new use; However, this renewed attention might be partly due to an increase in the number of patients with depression in recent years. In addition, more financial disclosures have reflected state and government support for this research. With an aging population, the application and side effects of clinical anesthetics will continue to attract attention. The continuous progress of ketamine research and the strong support of the government has facilitated the developments in the field of anesthesia to a certain extent.

Depression is a common mental illness. Existing antidepressants have a slow onset of action, usually 3-4 weeks, and the failure rate is high (up to 40\%) (Thase et al., 2005; Krishnan and Nestler, 2008). Therefore, rapid-acting and effective antidepressants need to be developed; this is a medical problem that needs to be solved urgently. Professor Krystal from the Department of Psychiatry at Yale University School of Medicine and others reported for the first time in 2000 and found that ketamine had a rapid antidepressant effect (Rmbab et al., 2000). A single intravenous infusion of ketamine $(0.5 \mathrm{mg} / \mathrm{kg})$ produced an effective antidepressant effect in $4 \mathrm{~h}$ and lasted for at least $72 \mathrm{~h}$. Zarate et al. (2006) conducted another randomized double-blind controlled study on patients with refractory depression using the same method of administration and dose, and the results showed that intravenous infusion with a subanesthetic dose $(0.5 \mathrm{mg} / \mathrm{kg})$ of ketamine improved the symptoms of depression significantly in $110 \mathrm{~min}$ after administration. About $71 \%$ of the patients showed a significant improvement in their depression symptoms, and $29 \%$ of the patients felt relieved 1 day after the administration (Zarate et al., 2006). Price et al. (2009) once again confirmed the rapid and effective antidepressant effect of ketamine and found that it can effectively alleviate or eliminate suicidal ideation in depression patients within $24 \mathrm{~h}$ after administration. From 2010 to 2015, Professor Zarate's research team reported a series of research results on the clinical efficacy of ketamine as an antidepressant. These results showed that ketamine could produce rapid, effective, and long-lasting antidepressant effects (Zarate et al., 2012; Ionescu et al., 2015; Moaddel et al., 2015); ketamine not only quickly alleviated the patients' depression symptoms but also attenuated their suicidal tendencies (Ballard et al., 2014). The antidepressant effect of ketamine was first discovered in the clinic, followed by many animal experiments to explore the molecular targets of ketamine and the related mechanism of action. Ketamine has been demonstrated to have significant antidepressant effects in a variety of classic depression models (Maeng et al., 2008; Li et al., 2010; Autry et al., 2011; Beurel et al., 2011; Xu et al., 2013; Zhou et al., 2015).

Several highly cited studies discussed the mechanism and duration of ketamine' antidepressants effect. The study by Maeng et al. (2008) hypothesized that a-amino-3-hydroxy-5methylisoxazole-4-propionic acid (AMPA) receptor throughput facilitated ketamine' antidepressant effects. Ketamine was administered at doses of $0.5,2.5$, and $10 \mathrm{mg} / \mathrm{kg}$, and single injections of ketamine can produce rapid antidepressant effects (Maeng et al., 2008). For the persistence of the antidepressant effect of ketamine, Maeng et al. (2008) treated mice with saline, ketamine $(2.5 \mathrm{mg} / \mathrm{kg})$ and imipramine $(20 \mathrm{mg} / \mathrm{kg})$ and found that only mice in the ketamine group had lower immobility after 
TABLE 5 | Ranking of the top 20 journals by citations.

\begin{tabular}{|c|c|c|c|c|c|c|}
\hline Order & Name & Number of posts & Number of cited & Citations per article & IF & JCR partition \\
\hline 1. & Anesthesia and Analgesia & 129 & 5,984 & 46.39 & 5.178 & Q1 \\
\hline 2. & Veterinary Anesthesia and Analgesia & 108 & 1,506 & 13.94 & 1.648 & Q2 \\
\hline 3. & Psychopharmacology & 105 & 3,673 & 34.98 & 4.53 & Q2 \\
\hline 4. & Anesthesiology & 81 & 4,487 & 55.4 & 7.892 & Q1 \\
\hline 5. & Pediatric anesthesia & 75 & 1,811 & 24.15 & 2.556 & Q2 \\
\hline 6. & Neuropsychopharmacology & 68 & 4,071 & 59.87 & 5.251 & Q1 \\
\hline 7. & British Journal of Anesthesia & 58 & 1,853 & 31.95 & 9.166 & Q1 \\
\hline 8. & Journal of Affective Disorders & 58 & 1,482 & 25.55 & 4.839 & Q1 \\
\hline 9. & Behavioral Brain Research & 57 & 1,279 & 22.44 & 3.332 & Q2 \\
\hline 10. & $\begin{array}{l}\text { American Journal of Veterinary } \\
\text { Research }\end{array}$ & 56 & 1,036 & 18.5 & 1.156 & Q3 \\
\hline 11. & Journal of Zoo and Wildlife Medicine & 54 & 425 & 7.87 & 0.776 & Q3 \\
\hline 12. & Neuropharmacology & 54 & 1,664 & 30.081 & 5.251 & Q1 \\
\hline 13. & $\begin{array}{l}\text { Pharmacology Biochemistry and } \\
\text { Behavior }\end{array}$ & 54 & 1,197 & 22.17 & 3.533 & Q2 \\
\hline 14. & PLOS ONE & 54 & 1,242 & 23 & 3.24 & Q2 \\
\hline 15. & Biological Psychiatry & 49 & 5,991 & 122.27 & 13.382 & Q1 \\
\hline 16. & Acta Anaesthesiologica Scandinavica & 48 & 1,438 & 29.96 & 2.105 & Q4 \\
\hline 17. & $\begin{array}{l}\text { American Journal of Emergency } \\
\text { Medicine }\end{array}$ & 47 & 999 & 21.26 & 2.469 & Q2 \\
\hline 18. & Journal of Psychopharmacology & 47 & 1,502 & 31.96 & 4.153 & Q2 \\
\hline 19. & Neuroscience Letters & 47 & 692 & 14.72 & 3.046 & Q3 \\
\hline 20. & $\begin{array}{l}\text { International Journal of } \\
\text { Neuropsychopharmacology }\end{array}$ & 43 & 1,942 & 45.16 & 5.176 & Q1 \\
\hline
\end{tabular}

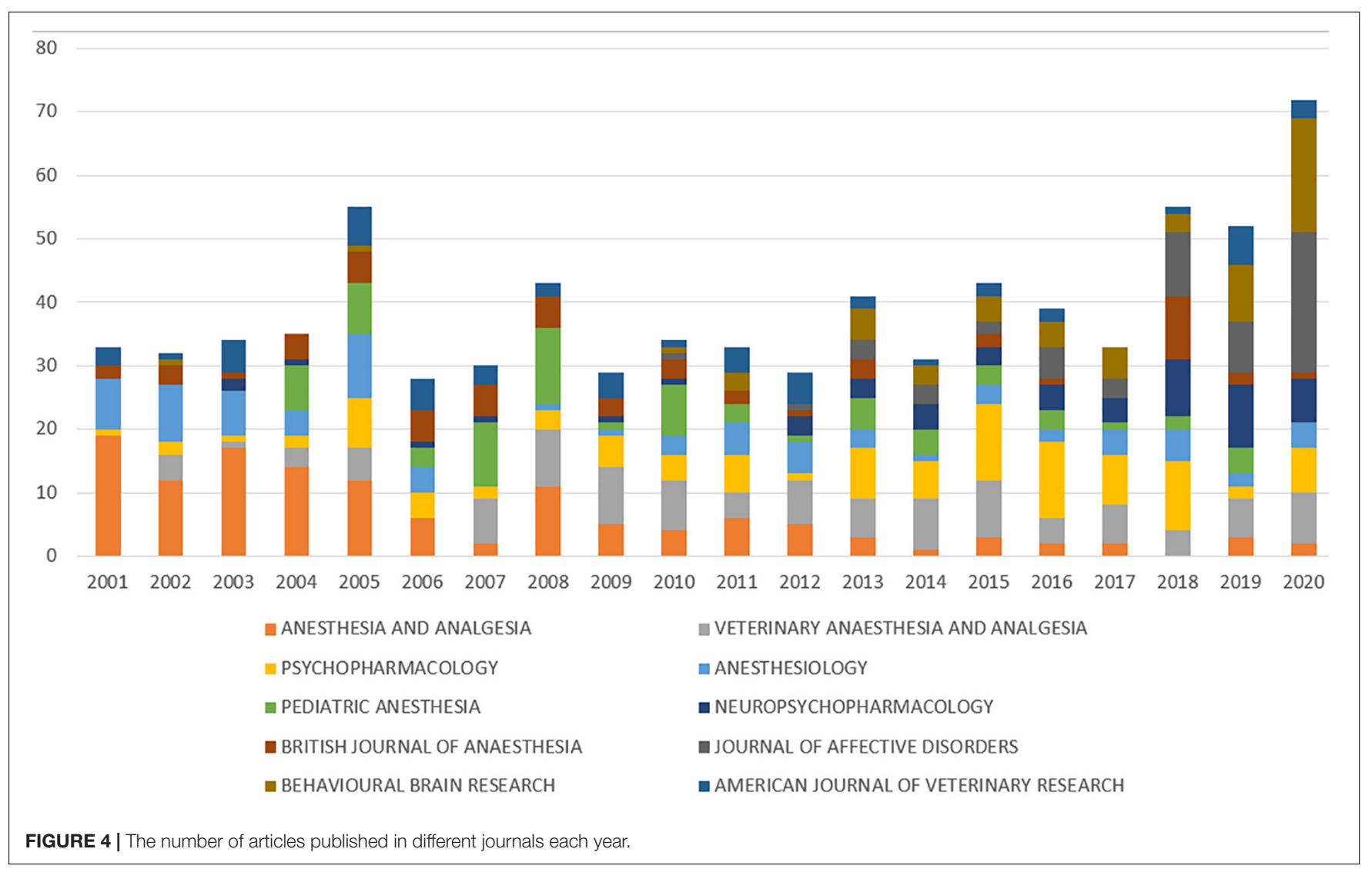


A

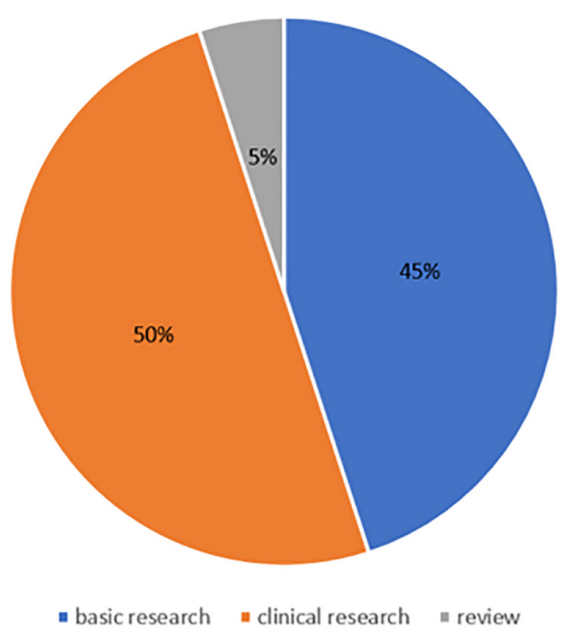

C

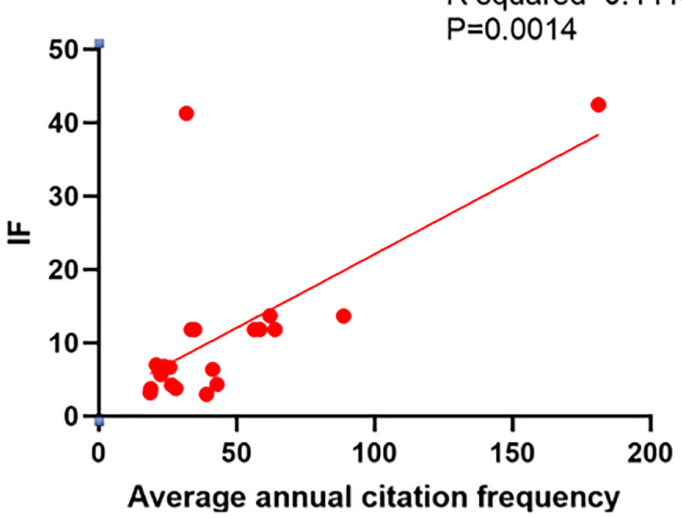

B

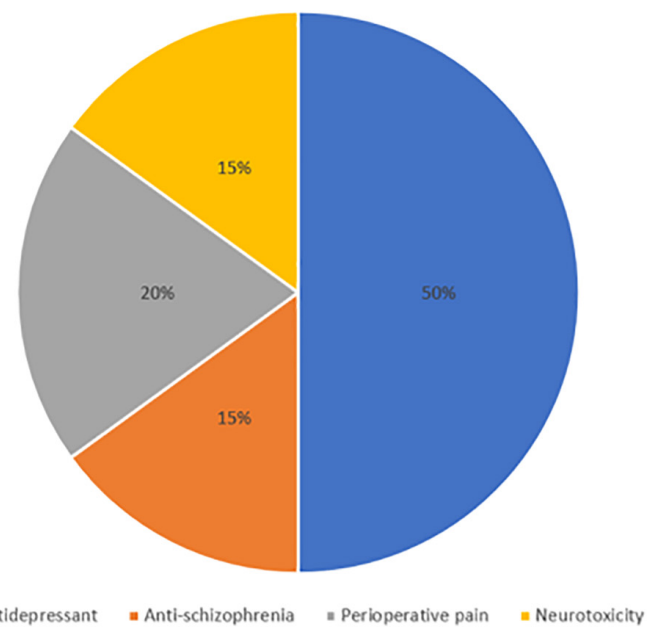

D

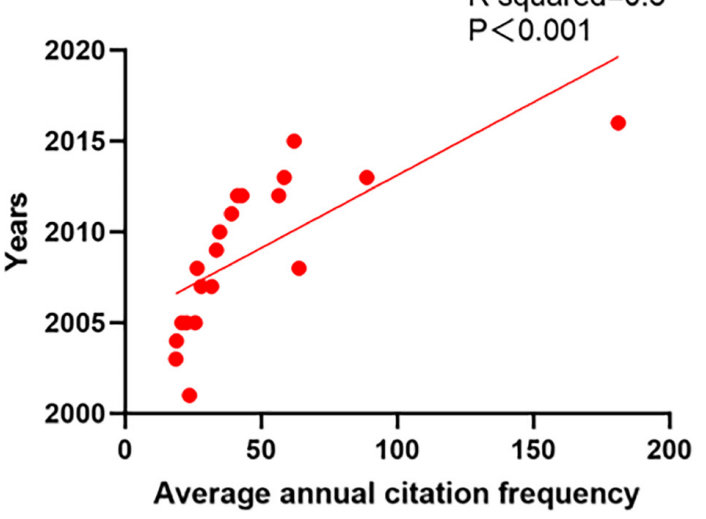

FIGURE 5 | The classification and correlation analysis of the top 20 cited articles on ketamine. (A) The proportions of the top 20 ketamine research article classifications. (B) The proportions of the research content categories of the top 20 cited articles on ketamine. (C) There was a significant correlation between the average number of citations per year and the impact factor based on the correlation analysis (R squared $=0.4419 ; P=0.0014)$. (D) There was a significant correlation between the average number of citations per year and the year of the analysis (R squared $=0.5 ; P<0.001)$.

2 weeks, suggesting that the ketamine' antidepressant effect lasted for a fortnight. The mice were then fear-trained and treated with saline and ketamine and it was found that ketamine did not result in memory impairment. The duration of ketamine induced immobility was shortened after the use of AMPA receptor antagonists. The use of AMPA antagonists significantly blocked the antidepressant effects of MK-801 (a non-selective NMDA antagonist) and Ro25-6981 (a selective NR2B antagonist), and interestingly, neither of them had as long-lasting antidepressant effects as ketamine. Zanos et al. (2016) elaborated that the antidepressant actions of ketamine was NMDA receptors independently, but with AMPA receptor activated. Zanos et al. (2016) also demonstrated the importance of the ketamine metabolite (2S,6S;2R,6R)-hydroxynorketamine (HNK) in the antidepressant effect at the molecular level. Compared with (2S,6S)-HNK from (S)-ketamine, (2R,6R)-HNK derived from (R)-ketamine established more potent antidepressant effect and showed a more pronounced dose dependence than S-ketamine, and that $(2 \mathrm{R}, 6 \mathrm{R})-\mathrm{HNK}$ showed no significant toxic effects compared to direct ketamine administration, suggesting R-ketamine will be more benefit as a new type of antidepressant drug. In the clinical randomized, double-blind add-on trial, Carlos reported an improvement in depressive symptoms within 3 days after the administration of $0.5 \mathrm{mg} / \mathrm{kg}$ ketamine injection for bipolar depression patients, with the most significant side effect being dissociative symptoms, which occurred 40 min after injection (Zarate et al., 2012). In another high-impact clinical research by Murrough et al. (2013) who used $0.5 \mathrm{mg} / \mathrm{kg}$ ketamine or $0.045 \mathrm{mg} / \mathrm{kg}$ midazolam single infusion in treatment-resistant major depression patients and showed that ketamine had a faster onset of action (dominance ratio 2.18) and higher efficacy (64\% for ketamine; $28 \%$ for imipramine). Therefore, the difference in study design, dose or disease states did not affect ketamine's antidepressant effect.

Through statistical analysis, we found that more ketamine articles are published in neuroscience. The possible reason is that many basic researches on ketamine have been published in large quantities, to figure out the mechanism of ketamine. 
TABLE 6 | Top 20 cited articles.

\begin{tabular}{|c|c|c|c|c|c|c|}
\hline $\begin{array}{l}\text { Rank } \\
\text { number }\end{array}$ & Topic & $\begin{array}{l}\text { Corresponding } \\
\text { author }\end{array}$ & Institution & Journal & Year & $\begin{array}{l}\text { Cited } \\
\text { frequency }\end{array}$ \\
\hline 1 & $\begin{array}{l}\text { Cellular mechanisms underlying the } \\
\text { antidepressant effects of ketamine: Role } \\
\text { of alpha-amino-3-hydroxy-5- } \\
\text { methylisoxazole-4-propionic acid } \\
\text { receptors }\end{array}$ & Manji, HK & $\begin{array}{l}\mathrm{NIH}, \text { Lab Mol Pathophysiol } \\
\text { and Expt Therapeut }\end{array}$ & Biological Psychiatry & 2008 & 766 \\
\hline 2 & $\begin{array}{l}\text { NMDAR inhibition-independent } \\
\text { antidepressant actions of ketamine } \\
\text { metabolites }\end{array}$ & Gould, TD & $\begin{array}{l}\text { University of Maryland } \\
\text { School of Medicine } \\
\text { Department of Psychiatry }\end{array}$ & Nature & 2016 & 724 \\
\hline 3 & $\begin{array}{l}\text { Antidepressant Efficacy of Ketamine in } \\
\text { Treatment-Resistant Major Depression: A } \\
\text { Two-Site Randomized Controlled Trial }\end{array}$ & Mathew, SJ & Icahn Sch Med Mt Sinai & $\begin{array}{l}\text { American Journal of } \\
\text { Psychiatry }\end{array}$ & 2013 & 621 \\
\hline 4 & $\begin{array}{l}\text { Replication of Ketamine's Antidepressant } \\
\text { Efficacy in Bipolar Depression: A } \\
\text { Randomized Controlled Add-On Trial }\end{array}$ & Zarate, CA & $\begin{array}{l}\mathrm{NIH} \text {, Department of Health } \\
\text { and Human Services }\end{array}$ & Biological Psychiatry & 2012 & 451 \\
\hline 5 & $\begin{array}{l}\text { Effects of ketamine in normal and } \\
\text { schizophrenic volunteers }\end{array}$ & Lahti, AC & $\begin{array}{l}\text { University of Maryland } \\
\text { School of Medicine } \\
\text { Department of Psychiatry } \\
\text { Research Center }\end{array}$ & Neuropsychopharmacology & 2001 & 448 \\
\hline 6 & $\begin{array}{l}\text { Ketamine-induced loss of phenotype of } \\
\text { fast-spiking interneurons is mediated by } \\
\text { NADPH-oxidase }\end{array}$ & Behrens, MM & $\begin{array}{l}\text { University of California San } \\
\text { Diego, Department of } \\
\text { Medicine }\end{array}$ & Science & 2007 & 413 \\
\hline 7 & $\begin{array}{l}\text { Rapid and Longer-Term Antidepressant } \\
\text { Effects of Repeated Ketamine Infusions in } \\
\text { Treatment-Resistant Major Depression }\end{array}$ & Murrough, JW & $\begin{array}{l}\text { Mount Sinai School of } \\
\text { Medicine }\end{array}$ & Biological Psychiatry & 2013 & 409 \\
\hline 8 & $\begin{array}{l}\text { Remifentanil-induced postoperative } \\
\text { hyperalgesia and its prevention with } \\
\text { small-dose ketamine }\end{array}$ & Chauvin, M & $\begin{array}{l}\text { Assistance Publique } \\
\text { Hôpitaux de Paris }\end{array}$ & Anesthesiology & 2005 & 386 \\
\hline 9 & $\begin{array}{l}\text { Effects of Intravenous Ketamine on } \\
\text { Explicit and Implicit Measures of } \\
\text { Suicidality in Treatment-Resistant } \\
\text { Depression }\end{array}$ & Price, RB & $\begin{array}{l}\text { Rutgers, The State } \\
\text { University }\end{array}$ & Biological Psychiatry & 2009 & 369 \\
\hline 10 & $\begin{array}{l}\text { Ketamine-induced neuronal cell death in } \\
\text { the perinatal rhesus monkey }\end{array}$ & Slikker, W & $\begin{array}{l}\text { U.S. Food and Drug } \\
\text { Administration's National } \\
\text { Center for Toxicological } \\
\text { Research }\end{array}$ & Toxicological Sciences & 2007 & 363 \\
\hline 11 & $\begin{array}{l}\text { Ketamine anesthesia during the first week } \\
\text { of life can cause long-lasting cognitive } \\
\text { deficits in rhesus monkeys }\end{array}$ & Paule, MG & $\begin{array}{l}\text { U.S. Food and Drug } \\
\text { Administration's National } \\
\text { Center for Toxicological } \\
\text { Research }\end{array}$ & $\begin{array}{l}\text { Neurotoxicology and } \\
\text { Teratology }\end{array}$ & 2011 & 351 \\
\hline 12 & $\begin{array}{l}\text { Safety and Efficacy of Repeated-Dose } \\
\text { Intravenous Ketamine for } \\
\text { Treatment-Resistant Depression }\end{array}$ & aan het Rot, M & University of Groningen & Biological Psychiatry & 2010 & 347 \\
\hline 13 & $\begin{array}{l}\text { Signaling pathways underlying the rapid } \\
\text { antidepressant actions of ketamine }\end{array}$ & Duman, RS & Yale University & Neuropharmacology & 2012 & 343 \\
\hline 14 & $\begin{array}{l}\text { Ketamine and postoperative pain }-\mathrm{a} \\
\text { quantitative systematic review of } \\
\text { randomized trials }\end{array}$ & Elia, N & University Hospitals Geneva & Pain & 2005 & 337 \\
\hline 15 & Ketamine use: a review & Curran, HV & $\begin{array}{l}\text { UCL, Clinical } \\
\text { Psychopharmacology Unit }\end{array}$ & Addiction & 2012 & 330 \\
\hline 16 & $\begin{array}{l}\text { Acute administration of ketamine induces } \\
\text { antidepressant-like effects in the forced } \\
\text { swimming test and increases BDNF levels } \\
\text { in the rat hippocampus }\end{array}$ & Quevedo, J & $\begin{array}{l}\text { Universidade do Extremo } \\
\text { Sul Catarinense }\end{array}$ & $\begin{array}{l}\text { Progress in Neuro- } \\
\text { Psychopharmacology and } \\
\text { Biological Psychiatry }\end{array}$ & 2008 & 317 \\
\hline 17 & $\begin{array}{l}\text { Effects of ketamine and } \\
\text { N-methyl-D-aspartate on glutamate and } \\
\text { dopamine release in the rat prefrontal } \\
\text { cortex: Modulation by a group II selective } \\
\text { metabotropic glutamate receptor agonist } \\
\text { LY379268 }\end{array}$ & Lorrain, DS & $\begin{array}{l}\text { Merck Research } \\
\text { Laboratories }\end{array}$ & Neuroscience & 2003 & 317 \\
\hline
\end{tabular}


TABLE 6 | (Continued)

\begin{tabular}{|c|c|c|c|c|c|c|}
\hline $\begin{array}{l}\text { Rank } \\
\text { number }\end{array}$ & Topic & $\begin{array}{l}\text { Corresponding } \\
\text { author }\end{array}$ & Institution & Journal & Year & $\begin{array}{l}\text { Cited } \\
\text { frequency }\end{array}$ \\
\hline 18 & $\begin{array}{l}\text { Potential of ketamine and midazolam, } \\
\text { individually or in combination, to induce } \\
\text { apoptotic neurodegeneration in the infant } \\
\text { mouse brain }\end{array}$ & Olney, JW & Washington University & $\begin{array}{l}\text { British Journal of } \\
\text { Pharmacology }\end{array}$ & 2005 & 312 \\
\hline 19 & $\begin{array}{l}\text { Ketamine and Other NMDA Antagonists: } \\
\text { Early Clinical Trials and Possible } \\
\text { Mechanisms in Depression }\end{array}$ & Nemeroff, CB & University of Miami & $\begin{array}{l}\text { American Journal of } \\
\text { Psychiatry }\end{array}$ & 2015 & 310 \\
\hline 20 & $\begin{array}{l}\text { Ketamine as adjuvant analgesic to } \\
\text { opioids: A quantitative and qualitative } \\
\text { systematic review }\end{array}$ & Subramaniam, K & Harvard University & Anesthesia and Analgesia & 2004 & 301 \\
\hline
\end{tabular}
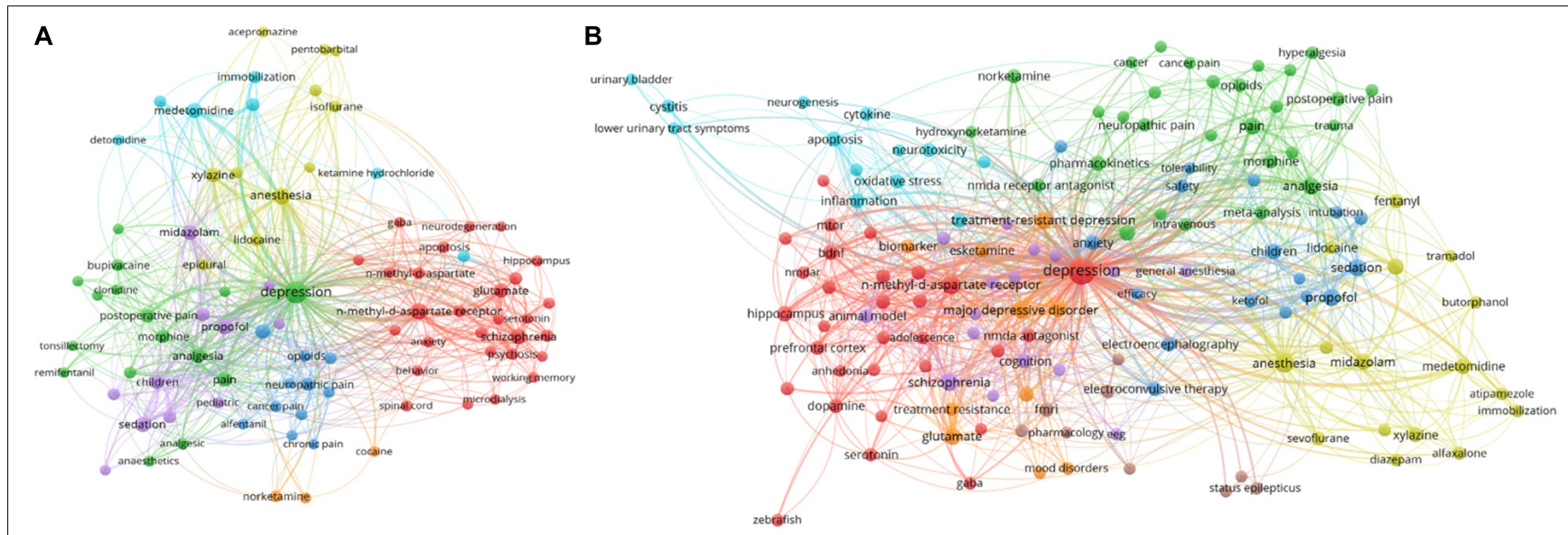

FIGURE 6 | A summary of the hotspot trends of articles on ketamine from 2001 to 2020 . The size of the circles and the thickness of the line represent the frequency of co-occurring keywords. (A) Hotspots of articles published on ketamine from 2001 to 2010. (B) Hotspots of articles published on ketamine from 2011 to 2020.

The following disciplines are pharmacology and psychology list second and psychiatry list third, due to the large number of published studies on the antidepressant effects of ketamine. The focus of different disciplines may also different. For example, the focus of anesthesia may be the application of anesthesia and the use of anesthesia techniques in clinical practice, while the focus of pharmacology maybe the pharmacological effects, toxicological effects, and half-life of drugs themselves. However, some of these disciplines like anesthesiology or neurosciences also intersect with each other, which can participate in both intraoperative anesthesia induction and antidepressant study of ketamine. The differences of topic hotspots or focus keywords among different disciplines would be analyzed in the further study.

Our bibliometric analysis had some inherent limitations. First, some recently published high-impact articles were not included in the "20 most cited articles" because they were not cited sufficiently. However, this does not mean that these articles were not important. Second, we found that articles published in journals with high impact factors tended to receive more attention. In the correlation analysis, we found that the impact factor and the average number of citations of the journal were positively correlated, which showed that high impact factors can inherently lead to bias.

\section{CONCLUSION}

We searched and analyzed 5192 English articles published on ketamine from 2001 to 2020. Despite some limitations, our study has found that research interest in ketamine has gradually increased. The research was mostly focused on the clinical application and mechanism of ketamine as an antidepressant, which has also led to more publications on ketamine in mental illness and veterinary journals. Moreover, basic scientific research on the antidepressant mechanism of ketamine has evidently in the past 10 years.

\section{DATA AVAILABILITY STATEMENT}

The original contributions presented in the study are included in the article/Supplementary Material, further inquiries can be directed to the corresponding author/s.

\section{AUTHOR CONTRIBUTIONS}

TZL and HQ conceived, designed the structure of this manuscript, and revised the manuscript. HHM, KY, DYG, 
XWL, YC, and XL analyzed and wrote the manuscript. All authors contributed to the article and approved the submitted version.

\section{FUNDING}

This study was funded by the Natural Science Foundation of Beijing (7212023), the Beijing Municipal Administration of

\section{REFERENCES}

Autry, A. E., Adachi, M., Nosyreva, E., Na, E. S., Los, M. F., Cheng, P.-F., et al. (2011). NMDA receptor blockade at rest triggers rapid behavioural antidepressant responses. Nature 475, 91-95. doi: 10.1038/nature10130

Ballard, E. D., Ionescu, D. F., Vande Voort, J. L., Niciu, M. J., Richards, E. M., Luckenbaugh, D. A., et al. (2014). Improvement in suicidal ideation after ketamine infusion: relationship to reductions in depression and anxiety. J. Psychiatr. Res. 58, 161-166. doi: 10.1016/j.jpsychires.2014.07.027

Beurel, E., Song, L., and Jope, R. S. (2011). Inhibition of glycogen synthase kinase3 is necessary for the rapid antidepressant effect of ketamine in mice. Mol. Psychiatry 16, 1068-1070. doi: 10.1038/mp.2011.47

Hirota, K., and Lambert, D. G. (1996). Ketamine: its mechanism(s) of action and unusual clinical uses. BJA Br. J. Anaesth. 77, 441-444. doi: 10.1093/bja/77.4.441

Ionescu, D. F., Luckenbaugh, D. A., Niciu, M. J., Richards, E. M., and Zarate, C. A. Jr. (2015). A single infusion of ketamine improves depression scores in patients with anxious bipolar depression. Bipolar Disord. 17, 438-443. doi: 10.1111/bdi.12277

Johnson, J. W., Glasgow, N. G., and Povysheva, N. V. (2015). Recent insights into the mode of action of memantine and ketamine. Curr. Opin. Pharmacol. 20, 54-63. doi: 10.1016/j.coph.2014.11.006

Krishnan, V., and Nestler, E. J. (2008). The molecular neurobiology of depression. Nature 455, 894-902.

Li, N., Lee, B., Liu, R.-J., Banasr, M., Dwyer, J. M., Iwata, M., et al. (2010). mTORDependent Synapse Formation Underlies the Rapid Antidepressant Effects of NMDA Antagonists. Science 329, 959-964. doi: 10.1126/science.1190287

Maeng, S., Zarate, C. A., Du, J., Schloesser, R. J., McCammon, J., Chen, G., et al. (2008). Cellular Mechanisms Underlying the Antidepressant Effects of Ketamine: role of $\alpha$-Amino-3-Hydroxy-5-Methylisoxazole-4-Propionic Acid Receptors. Biol. Psychiatry 63, 349-352. doi: 10.1016/j.biopsych.2007.05.028

Moaddel, R., Luckenbaugh, D. A., Xie, Y., Villaseñor, A., Brutsche, N. E., MachadoVieira, R., et al. (2015). D-serine plasma concentration is a potential biomarker of (R,S)-ketamine antidepressant response in subjects with treatment-resistant depression. Psychopharmacology 232, 399-409. doi: 10.1007/s00213-0143669-0

Murrough, J. W., Iosifescu, D. V., Chang, L. C., Al Jurdi, R. K., Green, C. E., Perez, A. M., et al. (2013). Antidepressant efficacy of ketamine in treatment-resistant major depression: a two-site randomized controlled trial. Am. J. Psychiatry 170, 1134-1142. doi: 10.1176/appi.ajp.2013.13030392

Price, R. B., Nock, M. K., Charney, D. S., and Mathew, S. J. (2009). Effects of intravenous ketamine on explicit and implicit measures of suicidality in treatment-resistant depression. Biol. Psychiatry 66, 522-526. doi: 10.1016/j. biopsych.2009.04.029

Rmbab, C., Ac, C., Aab, C., Dan, A., Grha, C., Dscab, C., et al. (2000). Antidepressant effects of ketamine in depressed patients. Biol. Psychiatry 47, 351-354.
Hospitals' Youth Programme (QML20200102), and the National Natural Science Foundation of China (82071180) to HHM.

\section{SUPPLEMENTARY MATERIAL}

The Supplementary Material for this article can be found online at: https://www.frontiersin.org/articles/10.3389/fnmol. 2022.839198/full\#supplementary-material

Schmid, R. L., Sandler, A. N., and Katz, J. (1999). Use and efficacy of low-dose ketamine in the management of acute postoperative pain: a review of current techniques and outcomes. Pain 82, 111-125. doi: 10.1016/S0304-3959(99) 00044-5

Thase, M. E., Haight, B. R., Richard, N., Rockett, C., Mitton, M., Modell, J. G., et al. (2005). Remission Rates Following Antidepressant Therapy With Bupropion or Selective Serotonin Reuptake Inhibitors: a Meta-Analysis of Original Data From 7 Randomized Controlled Trials. J. Clin. Psychiatry 66, 974-981. doi: 10.4088/jcp.v66n0803

Xu, S. X., Zhou, Z. Q., Li, X. M., Ji, M. H., Zhang, G. F., and Yang, J. J. (2013). The activation of adenosine monophosphate-activated protein kinase in rat hippocampus contributes to the rapid antidepressant effect of ketamine. Behav. Brain Res. 253, 305-309. doi: 10.1016/j.bbr.2013.07.032

Zanos, P., Moaddel, R., Morris, P. J., Georgiou, P., Fischell, J., Elmer, G. I., et al. (2016). NMDAR inhibition-independent antidepressant actions of ketamine metabolites. Nature 533, 481-486. doi: 10.1038/nature17998

Zarate, C. A. Jr., Brutsche, N. E., Ibrahim, L., Franco-Chaves, J., Diazgranados, N., Cravchik, A., et al. (2012). Replication of Ketamine's Antidepressant Efficacy in Bipolar Depression: a Randomized Controlled Add-On Trial. Biol. Psychiatry 71, 939-946. doi: 10.1016/j.biopsych.2011.12.010

Zarate, C. A. Jr., Singh, J. B., Carlson, P. J., Brutsche, N. E., Ameli, R., Luckenbaugh, D. A., et al. (2006). A Randomized Trial of an N-methyl-D-aspartate Antagonist in Treatment-Resistant Major Depression. Arch. Gen. Psychiatry 63, 856-864.

Zhou, Z., Zhang, G., Li, X., Liu, X., Wang, N., Qiu, L., et al. (2015). Loss of Phenotype of Parvalbumin Interneurons in Rat Prefrontal Cortex Is Involved in Antidepressant- and Propsychotic-Like Behaviors Following Acute and Repeated Ketamine Administration. Mol. Neurobiol. 51, 808-819. doi: 10.1007/ s12035-014-8798-2

Conflict of Interest: The authors declare that the research was conducted in the absence of any commercial or financial relationships that could be construed as a potential conflict of interest.

Publisher's Note: All claims expressed in this article are solely those of the authors and do not necessarily represent those of their affiliated organizations, or those of the publisher, the editors and the reviewers. Any product that may be evaluated in this article, or claim that may be made by its manufacturer, is not guaranteed or endorsed by the publisher.

Copyright $\odot 2022$ Miao, Yu, Gao, Lin, Cao, Liu, Qiao and Li. This is an open-access article distributed under the terms of the Creative Commons Attribution License (CC BY). The use, distribution or reproduction in other forums is permitted, provided the original author(s) and the copyright owner(s) are credited and that the original publication in this journal is cited, in accordance with accepted academic practice. No use, distribution or reproduction is permitted which does not comply with these terms. 